\title{
Endless Breath? The Pipe Organ and Immortality
}

\author{
Francis O'Gorman
}

To contemplate this progress of the greatest of musical instruments with full instruction, it must be remembered that in a development necessitating artificial and consequently wind supplies of fixed pressures, the chief source of natural expression in a wind instrument as secured by the varying breath of the performer was lost to the organ. This disaster became in the end the source of its glorious development, by challenging man's ingenuity to the utmost, in the production of a vast and complicated mechanism by which natural expression was to be attained, through a multiplicity of artificial appliances.

'Brindley and Foster',

The New Monthly Magazine, 122 (February 1883), 261-67 (261). ${ }^{1}$

$$
* * *
$$

F. O'Gorman ( $\square)$

Department of English Literature, University

of Edinburgh, Edinburgh, Scotland, UK

(C) The Author(s) 2021

D. Fuller et al. (eds.), The Life of Breath in Literature, Culture

and Medicine, Palgrave Studies in Literature, Science and Medicine, https://doi.org/10.1007/978-3-030-74443-4_15 
As everyone knows, reading aloud-poetry, drama, prose-requires us to accommodate the limited capacity of our lungs. It is no good to run out of breath mid-sentence or to breathe in a place that breaks or even changes the sense. This is equally true of words to be sung. The first version in the first edition of Hymns, Ancient and Modern (1861) of Frances Elizabeth Cox's Easter hymn-a translation from Christian Fürchtegott Gellert-collapses if a breath is taken at the end of the first line: 'Jesus lives! no longer now | Can thy terrors, Death, appal me'.2 There is, aptly in relation to Cox, always a contest with the grave in any voiced reading (which plainly includes singing). A long sentence tests us against the constraints of our own mortality. This is such a familiar issue that we are not always explicitly conscious of it. Judging where to breathe, and where not, is a standard feature of the oral performance of literature as much as in singing. But on poems about, for instance, the possibilities_-or impossibilities — of living forever, or simply poems that represent the experience of the sorrow of loss, the question of breathing becomes more intimate with meanings. As the reader arranges his or her breathing to make best sense of lines, an expressive tension is set up with that which has, like Cordelia at the end of Shakespeare's play, no earthly breath at all. Here is Wordsworth, in a sonnet that needs careful preparation for reading aloud because of its elongated syntax and extended enjambment:

Surprised by joy-impatient as the Wind I turned to share the transport- $\mathrm{Oh}$ ! with whom

But Thee, long buried in the silent Tomb, That spot which no vicissitude can find? Love, faithful love, recalled thee to my mindBut how could I forget thee?-Through what power, Even for the least division of an hour, Have I been so beguiled as to be blind To my most grievous loss!-That thought's return Was the worst pang that sorrow ever bore, Save one, one only, when I stood forlorn, Knowing my heart's best treasure was no more; That neither present time, nor years unborn Could to my sight that heavenly face restore. ${ }^{3}$

An impatient wind is a figure that marks as much as it diverts what Wordsworth does quietly with breath in this poem. An impatient wind, for a start, is a gust met here with an absence, one that might be eternal. 
The spot where there are no vicissitudes is the grave, where no breath is ('heart's best treasure', interestingly, contains the word 'breath', scattered and broken). The briefly gusting wind is as fitful as human breath-the three-year-old Catherine's breathing that is over, and our breath as we read this poem aloud, breaking long grammatical units so that we do not run out of breath.

Breath easily marks the existence of life just as its absence works as a peculiar indicator of the grave. The substitution of breath for life, a synecdochic exchange, is part of the lingua franca of literature's signification both of life and its fragility. Stilled breathing is Lear's confirmation of his daughter's death; signs of breathing are part of Leontes' realisation that Hermione lives in The Winter's Tale. 'He breathed his last' is, far from Shakespeare, still a cliché for dying. In turn, the notion of endless breath, or rather of a capacity to breathe without ending, is both an appealing hint of immortality and an absurd one. Absurd because it has its own impossibility deep within it. It might be that part of the enormous imaginative attraction of the human mind to the whale is the cetacean's capacity to hold its breath far beyond human endurance. The whale is an evolutionary step closer, perhaps, to that which breathes but is not circumscribed by the tiny limits of human lungs. But whales must breathe eventually even if they cannot cry. Unceasing breathing, breath that is a sign of immortality not morality, haunts and bothers. When the 'Beat' poet Lawrence Ferlinghetti (1919-21) conjured the notion of endless days in his poem 'Endless Life', included in his These Are My Rivers (1993), he reached for the fantasy of inexhaustible breath-but then symptomatically hedged it with temporality in recognition of its real unreachability. '[E]ndless air and endless breath', Ferlinghetti wrote,

\section{Endless worlds without end of days in autumn capitals their avenues of leaves ablaze[.] ${ }^{4}$}

Time comes in-autumn, the Yeatsian turning of the leaves-even with the invocation of respiration that cannot cease and its implication of that which is outside time. Endless breath is too impossible a dream. It must be clocked out.

If endless breath is not for human beings, it is perhaps no wonder that some poets have attended to its figurative possibility in music. Only one inanimate object has been through history habitually described as 
having lungs or as being capable of a kind of mechanical 'breathing'. Sometimes, to be sure, steam locomotives have been described as if their steam were breath; ${ }^{5}$ vast marshes or quicksands have seemed to breathe; and we are now familiar with the notion of the great forests as the 'lungs' of the world and the perils to our literal breath of their destruction by human beings. But the vocabulary of breath has for many centuries been more-than-established for describing the pipe organ: by listeners, players, and organ builders. Producing what organ builders call 'wind' through a range of different systems-bellows or blowers, essentially-the organ stores that wind at the required pressures in chests. The wind is released by the depressing of a key or keys to enter, usually via pallets (valves), the pipe or pipes that have been selected by the player. The earliest organs of which we have knowledge are not fundamentally different to the instruments played today. The earliest known are from the ancient Mediterranean-'organ' comes from the ancient Greek ôp [tool, instrument]. These devices produced a tremendous sound-W. $\mathrm{H}$. Auden was not wrong in choosing that adjective for St Cecilia's instrument ${ }^{6}$ - for public celebrations and their wind was, often enough, supplied and its pressure retained, by water.

In Europe in the Middle Ages, different types of instruments developed-table-top organs, for instance, as well as cathedral organs that were recognisably related to the Greek and Roman instruments. ${ }^{7}$ The organ of Winchester Cathedral, for example, could apparently be heard throughout the town: it was played with fists on huge keys, blasting out a plainsong or cantus firmus, or playing the organum, a consistent interval above the sung chant. ${ }^{8}$ Here was air made into music-of a sort. And there is no difficulty in thinking of that air as a form of breath. The association became more obviously explicit with the more refined instruments of the post-Reformation seventeenth century as documented by poets. Milton, who played the organ and drew on its vocabulary periodically, thought, for example, of the construction of Pandemonium in Book 1 of Paradise Lost (1667) via a metaphor from organ design. 'A third [hole] as soon had form'd within the ground', Milton writes:

A various mould, and from the boyling cells

By strange conveyance fill'd each hollow nook,

As in an Organ from one blast of wind

To many a row of Pipes the sound-board breaths.

Anon out of the earth a Fabrick huge

Rose like an Exhalation, with the sound 
Of Dulcet Symphonies and voices sweet, Built like a Temple, where Pilasters round Were set, and Doric pillars overlaid With Golden Architrave[.] $]^{9}$

The organ and breath: an instrument associated for the Puritan Milton with Catholic worship (the Civil War, of course, saw the destruction of many instruments as had the Reformation earlier), ${ }^{10}$ the organ is here made to figure the building, the breathing into being, of the capital city of Hell. It is, nevertheless, easy to see that Milton the musician cannot avoid writing also of the wonder and sweetness of the instrument that the Irish poet Nicholas Brady (1659-1726) called, in the libretto to Henry Purcell's 'Hail! Bright Cecilia' (first performed 1692), the 'Wondrous machine'. ${ }^{11}$ And it is in Brady's libretto-derived in part from Dryden's 'Song for St Cecilia's Day' (1687) — that there is also an extended example of the trope in which I am interested. It was a trope, in relation to a fact of material history, that became of peculiar suggestiveness in the nineteenth century. Envisaging the organ, Brady sees that its breath can sometimes come from the realms of the immortal. 'With what', he asks,

sublime Celestial Lay

Can any Earthly Sounds compare?

If any Earthly Music dare,

The noble Organ may.

From Heav'n its wondrous Notes were giv'n,

(Cecilia oft convers'd with Heaven,)

Some Angel of the Sacred Choire

Did with his Breath the Pipes inspire;

And of their Notes above the just Resemblance gave,

Brisk without Lightness, without Dulness Grave. ${ }^{12}$

Not implicitly but directly, Brady observes that the organ's breath is that of angels. Once God breathed literal life into Adam in Genesis 2:7; so another act of respiration brings, instead, echoes of the music of the heavens to humanity through the organ.

But this connection between a musical instrument and the breath of immortal beings - breath that cannot die, breath that is a foretaste or, rather, fore-hearing of eternity-took, I think, a fresh form with the development, in the nineteenth century, of more sophisticated forms of organ blowing. A feature of the material history of a musical instrument 
prompted, I propose, an intensification of imaginative possibilities implicit in its earlier history. With the refining of water pressure systems, then steam and gas systems, and eventually electrically powered systems, ${ }^{13}$ it became theoretically possible for the organ-even a very large one-to be supplied with wind indefinitely. Industrialisation in the nineteenth century dramatically enhanced the instrument's power and resources even if it did not alter its essential nature. The celebrated British organ builder Henry Willis (1821-1901) helped radically change the nature of the British organ. Together with the very different style of instruments constructed by William Hill (1789-1870), Willis created organs that remain some of the nineteenth century's finest achievements in pipe organ design. ${ }^{14}$ Willis's instrument for the 1851 Great Exhibition was distinctively important. The Crystal Palace organ was-in the terms of the day-large, comprising seventy speaking stops over three manuals and pedals (coincidentally it now forms the basis of the organ of Winchester Cathedral). ${ }^{15}$ With a version of pneumatic action to Great and Swell, the two principal divisions in most British organs, where wind pressure assists with the organ's internal mechanisms, the instrument could be said in several senses to rely on a figurative exhalation and inhalation. Powered by steam, Willis's even more famous instrument for St George's Hall, Liverpool (1855), required three eight horse-power engines to keep it going. ${ }^{16}$ Not reliant on merely human force, Willis's show-case Liverpool organ could, far better than the whale, hold its breath in ways inconceivable to a man. Here the organ with its potentially endless sound could, in turn, more satisfactorily associate itself with the dreams of life that could not die. With the lungs of the modern organ-producing, said The Musical Standard in 1881, assuming the complete interchangeability of the nouns, 'wind or breath', ${ }^{17}$ - it was possible to envisage intimations of eternity around us.

A small but interesting corpus of poems - and some other writingin the second half of the nineteenth century muses on the relationship between this instrument and the divine, or at least the sublime. And that writing also muses on the eternal. Of course, this is most but not exclusively true when the organ in question is in a church, where, often enough, the invisibility of the organist and/or the loftiness of the instrument's placing (many larger organs being situated on chancel or triforium screens or in galleries) add to the solemnity of the building and enhance the sense of the organ speaking from, and of, another domain. But secular 
locations did not by any means exclude the possibility of the organ's other-worldliness.

The Canadian poet Arthur Weir (1864-1902), thinking of a church, published 'At the Recital' in 1890, describing, in what was not an original trope, the poet caught between earth and eternity, summoned by the organ's sound:

Midway between the world and God we sate,

While through the church the Spirit of Music stole, And in its robes harmonic wrapped us twain.

Of thy pure soul, from evil free and hate, Then [it] woke my heart to hear the grand refrain, And yearned to reach, like thee, life's noblest goal. ${ }^{18}$

There is no direct mention of 'breath'. But the explicit association between the experience of listening to the organ and a desire to reach eternity catches, it might be, the reinvigorated possibility of large instruments powered by a theoretically unceasing energy source. For Edmund Gosse (1849-1928), fewer than twenty years after Willis's grand instrument for St George's Hall, the organ had become so intimately associated with the heavens, with the unchanging sphere above us, that it was no longer a mediator between humanity and the eternal but a feature of eternity itself. Gosse's Calvinist father, Edmund recalled in his memorable account of his childhood, Father and Son: A Study of Two Temperaments (1907), had always 'fortified his religious life by prayer as an athlete does his physical life by lung-gymnastics'. 19 In the organ, Gosse discerned the religious life fortified by nothing so strenuous but, rather, by unheard music of a different kind from Keats's. 'The golden spheres are God's sublime citole', Gosse observed in 'The Music of the Spheres' (1873),

Whereon His spirit like a plectrum flies,

But those seraphic organ-harmonies

Are silent to the hearing of man's soul;

Their deep symphonic rapture cannot roll

Across the ear of cold mortalities; ${ }^{20}$

This is a late nineteenth-century poem so wedded to the conception of the organ as an instrument of eternity that it cannot turn itself to the sound of the terrestrial organ at all. 
But sometimes the association between the organ and the unchanging realms of eternity was much more explicitly associated with the new technologies of organ blowing-with breath itself. For the energetic poet, Lakesman, supporter of The National Trust, and clergyman, Hardwicke Drummond Rawnsley (1851-1920), the very experience of watching an organist playing - and here in a secular location-brought him to the edge of the eternal. And we can be more exact than with Gosse. For Rawnsley was listening to another instrument by Henry Willis: the four-manual and pedal instrument at Colston Hall, Bristol. This organ was built in 1870 (and completely destroyed in a fire in 1898). Demanding more wind than the Great Exhibition organ, the instrument needed supplies-produced from three hydraulic engines-which would support, for example, a 32' pedal flue and a 16' Bombarde also on the pedal, big reeds at 16', 8' and 4', and a 'Tuba Major' on the solo division. ${ }^{21}$ It would have taken a hard-working team of foot- or hand-blowers to have created the necessary reserves and pressure to wind this instrument. 'I saw', Rawnsley writes, in his 'The Saturday Organ Recital in Colston Hall' (1877),

thy hands ascending and descending

The four white steps of yielding ivory;

And, either side, a sweet-tongued company,

That, bowing, made a welcome never ending,

Now this, now that, by their own words commending

The skill that taught thee so to touch the key,

And to the palace gate conducting thee,

Where winds and angels were in voice contending! ${ }^{22}$

It is to the very edge of heaven, where the immortals are, that this player-his identity I cannot discover-is taken. And at that edge, on the cusp of eternity, the difference between earth and heaven is marked in Rawnsley's imagination by the blending, or rather contending, of wind and the angels. Wind, that seemingly endless supply that the new organ offered, might be in the background-in the air, so to speak-of this visionary combination of Henry Willis with Paradise, of the new modern organ and the gateway to the eternal. (It is a rather odd irony, from the perspective of modern medicine, that the donor for the Colston Hall organ was William Henry Wills, first baron Winterstoke (1830-1911), whose vast fortune came from what we now know as the breath-impeding business of selling tobacco.) 
The breath of the organ and the certainty of immortality could, in the age of artificially powered wind supplies, even become part of quirky visions beyond, as Rawnsley has it, the palace gates themselves. The Manx poet and scholar T. E. Brown (1830-1897) contributed perhaps the most peculiar of all tributes to a deceased organist, his odd yet affectionate salute to Samuel Sebastian Wesley (1810-1876), who with Mendelssohn was the most influential of all organists and church composers in, and for, England in the first half of the nineteenth century. Brown does not merely envisage the organist taking one to the edge of heaven. The poem, 'The Organist in Heaven', figures Wesley in heaven, playing an instrument not built by hands. Brown's conceit is that when Wesley dies and is welcomed to his eternal home, the gate is temporarily left open, and the poet sneaks in. There he sees God constructing an organ out of thunders and great rivers for Wesley to play. The poet catches only the first moments of Wesley's performance on this vast instrument of and in eternity before he is chased out-a reversal of Catherine in Wuthering Heights (1847)—back to earth. 'Then certain angels', Brown imagines whimsically,

\footnotetext{
clad the Master

In very marvellous wise,

Till clouds of rose and alabaster

Concealed him from mine eyes.

And likest to a dove soft brooding,

The innocent figure ran;

So breathed the breath of his preluding,

And then the fugue began-

Began; but, to his office turning,

The porter swung his key;

Wherefore, although my heart was yearning,

I had to go; but he

Played on; and, as I downward clomb,

I heard the mighty bars

Of thunder-gusts, that shook heaven's dome,

And moved the balanced stars. ${ }^{23}$
}

However strange the poem, it makes distinctive use of the connections I am reflecting on here. The breathing of the organ, and its thundergusts, literally belong to the unchanging realm in this oddly unmetrical, unmusical salute to Wesley-with its half-allusion to Dante at the endas, perhaps, the modern instrument's sources of power fortified and gave 
fresh life, if I may so phrase it, to what the instrument had long implied of its relationship with the heavens. We have, in this poem, reached an extreme point. The audacity of Brown's connection, the now immortal organist playing on a heavenly organ, rather-takes one's breath away.

And yet $\ldots$ and yet ...

It is one thing to speculate that some poetry on the organ's longestablished connection with the sublime was revitalised by the theoretical possibilities of an unending wind supply from the middle of the nineteenth century onwards. But it is another to consider what in practice the technologies, both new and old, of organ winding could actually involve in the century. The nineteenth-century organist, whether playing a hand-blown or a mechanically blown instrument, had risks and troubles. Hand blowing, to start with the technologies that would gradually be replaced, had the obvious limitation of human weariness. Breath of both literal and metaphorical kinds can fail. For the young Irish poet Edmund John Armstrong (1841-1865), such failure prompted satirical exploration of near-farcical scenes in 'Old St Patrick's Cathedral, Dublin', included in his posthumous Poetical Works (1877). His subject was the chaotic forms of the Cathedral's worship including an organ blower-a man not a machine-about to keel over. 'This Anthem,' one voice says in the poem, as if talking about the theatre,

Obtains a two-nights' run.

being a favourite piece,

Bellows-Blower I:

Blow, Timothy! What are you gaping at? Blow!

The choristers form in procession below!

\section{Bellows-Blower II:}

This labour would bring Tubal-Cain to his death.

I tell you, I've blown till I'm quite out of breath. ${ }^{24}$

The near collapse or, rather, non-starting, of the Christmas anthem is the organ running out of breath because Timothy, the poor organ blower whose name, ironically, derives from the Greek 'honouring God', has run out of breath too. Fragility and the organ, failure and the cessation of breath, belong together. 
The similar weariness of the hand-blower, and thus the precariousness of the organ's breath, formed a topic, likewise, for the admired American author of The Autocrat at the Breakfast-Table (1858), Oliver Wendell Holmes (1809-1894). This is the subject of his evangelical poem, 'The Organ-Blower', included in his posthumous Complete Poetical Works (1912). Although it might be possible to read this poem ironically, or even mockingly, it is also legible as a sincere tribute to the men who, before the artificially powered systems, made the organ possible to play, and who, in turn, offered-for those willing to see it this way-a form of ministry. Where Montaigne reflected in 'On the Cannibals', that 'We grasp at everything but clasp nothing but wind', ${ }^{25}$ wind itself, where the organ was concerned for Holmes, figured instead the summation of everything. Watching the organ-blower at work, Holmes' poet is taken up with the sense of his, the organ-blower's, vocation, and, moved by a recognition of this implicit religious calling, the poet relieves the weary man directly. Here, unlike for Armstrong, the organ's association with failing breath is transformed into an opportunity for human service in the worship of the divine. The ending and the endless are intertwined. 'Not all the preaching', Oliver Wendell Holmes writes at the close of his long poem,

\section{O my friend,}

Comes from the church's pulpit end!

Not all that bend the knee and bow

Yield service half so true as thou!

One simple task performed aright,

With slender skill, but all thy might,

Where honest labor does its best,

And leaves the player all the rest.

This many-diapasoned maze,

Through which the breath of being strays,

Whose music makes our earth divine,

Has work for mortal hands like mine.

My duty lies before me. Lo,

The lever there! Take hold and blow!

And $\mathrm{He}$ whose hand is on the keys

Will play the tune as He shall please. ${ }^{26}$

God Himself is the organist here-a more breath-taking proposition than Brown's. The 'hand $[\ldots]$ on the keys' is both that of the organist playing 
on the manuals as well as, dimly, perhaps, the Father who allows His Son to give the keys of heaven to St Peter. But failure and perfection are united here. God's music is mortal because it is dependent on the strength of men who wear themselves out. But it is also bound to the eternal because it is God's. The organ, for Holmes, becomes at once the instrument of immortality-indeed, of God-as-organist-and an emblem of the Fall, exposing man's weakness and his need for relief.

The new technologies, I have suggested, implied the theoretical possibility of endless breath. But, as every organist still knows well, those technologies do not always work. Men at the bellows weary, but machines break down. The most memorable stories, narrated with a particular relish by Laurence Elvin, the author of, to my knowledge, the only extended history in English of organ blowing, are not of endless breath but its opposite. ${ }^{27}$ Hand-blowers suggested the organ's supply of wind could be unsteady. But so did the malfunctions of the industrial age. Here are some tales. Dr G. B. Arnold, organist of Winchester Cathedral (1865-1902) and one of the founder members of the (Royal) College of Organists, once experienced the partial failure of his hydraulic wind supply during his sortie, causing - as always happens - the organ to sink badly out of tune before it gave up altogether. 'After the service', Elvin says, 'an unmusical member of the congregation went up to the Doctor and said: "That voluntary you have just played was excellent, it reminded me so of the waves of the sea". One can imagine Dr Arnold's indignation!'. ${ }^{28}$ Elvin narrates, too, in his survey of failing wind supplies, an anecdote about choirboys mischievously messing with the similarly hydraulic blowing system at Manchester Cathedral, causing the resident organist Dr Kendrick Pyne's concluding improvisation to end not with a blaze of fanfare reeds but a feeble wail as the supply packed in. ${ }^{29}$ Famously, too, the steam engines of the already discussed Willis organ in St George's Hall, Liverpool-still one of the great Romantic instruments of the United Kingdom-once failed in a Saturday evening recital in 1913 when one of the cranks cracked. ${ }^{30}$ The dependence of the organist's art on machinery must have felt all too real to the Liverpool audienceassuming that this story is true-as they queued to leave a prematurely silenced concert, which no one could resume without the skill of a man who might be equally, if not more, at home in the boiler rooms of a transatlantic liner. The sound of the St George's Hall organ is still remembered as being hailed an industrial triumph (rather than anything to do 
with the mysteries of religion: it was as much a success as, indeed, a great ship). ${ }^{31}$

None of this could have nurtured the idea of the organ as able to breathe indefinitely. And it is worth remembering, too, that there were other major problems with the new technologies. The early steam-power engines, for example, needed hours of notice before they produced wind at the correct pressure. However important Willis's organ was for St George's Hall, the organist had to give the engineers twenty-four hours' notice in order for the engines to produce sufficient steam. ${ }^{32}$ There was no spontaneous practising here. Where the theoretical possibility of the organ's endless breath might have quietly re-energised late nineteenthcentury writing about the immortals, it could well have seemed to other listeners and players, hearing wheezing, out-of-tune, or simply silent instruments, that the organ was perfectly capable of suggesting death. Its failure to breathe could remind listeners of what will in due course occur to us all. Here, then, in the semiotics of the organ blower (to use a grand phrase), is something like William Empson's ambiguity of the seventh type. That is where the expression of an idea or image has within it exact contraries. With the established notion of the organ's winding as a form of breathing we have at once a figure of the organ and endless life-and its opposite.

It is not, though, in literary writing in the second half of the nineteenth century that this seventh ambiguity—an idea given to Empson, Sir Jonathan Bate thinks, by Einstein's General Theory of Relativity ${ }^{33}$ —was most notably explored. And it was not in writing in words either. John Cage's ASLSP (As Slow as Possible) (1985/7) is an organ piece currently in performance that exploits the potential of the instrument to continue indefinitely. The piece started being played at the church of St Burchardi, Halberstadt, in 2001, on a specially made organ with six pipes, and is planned to last for 639 years. ${ }^{34}$ It will end, that is to say, in September 2640. But for the esteemed Estonian composer for the church, Arvo Pärt (b. 1935), ${ }^{35}$ the organ's relationship with the seemingly perpetual and the enduring has been explored differently.

Pärt is a minimalist, absorbed by the inheritance of the Christian West, including that of plainchant. Fascinated by the associations between the contemporary and the far past, he was also, in his 1980 work for organ, Annum per Annum, energised by the aural experience of rising and failing breath as it could be suggested by the organ's wind chests. Annum per Annum was written to celebrate the 900 years in which a daily mass has 
been said in the Speyerer Dom, the ancient cathedral of the south-western German town of Speyer. Characteristically minimalist in musical material, with continuously repeated motifs across the five principal movements (corresponding to the Ordinary of the Mass), the piece epitomises the intensity and deep structural balance that Pärt can create through largely harmonic and simple patterns. But, ruminating on the durability of the Mass in the Speyerer Dom, Pärt was prompted to do something highly unusual in the history of the organ repertoire: to instruct the organist to switch the blower off during the course of the piece (this will not, of course, work with an electronic organ). The result, inevitably, is the rapid collapse of pitch and regularity of sound as the organ's lungs are emptied, and then its silence. György Ligeti's Volumina (1962), it might be added, does something related: this violently discordant work commences with the player instructed, with the instrument turned off, to depress a massive tutti cluster and then to switch on the wind. In its trial performance, this requirement caused the organ motor at the church at Göteborg, the planned scene of the first performance, to burst into flames. ${ }^{36}$

Pärt's dramatic gesture prompts the listener, perhaps, to consider music's relationship to time. Commemorating a long unbroken succession of worship in the Cathedral, the failing of the wind conjures the inevitable ending even of such durability, the last day. Mortal things will not endure. But then, with the blower switched back on, Pärt's strange, insistent music resumes as if figuring not only temporal fragility but reanimation, the God-like revival through a saving, returning breath. Another ambiguity of the seventh type, perhaps, Pärt's Annum per Annum deploys the organ's lungs to create in sound a reminder of what will, and will not, last.

And finally ...

Is there any merit in thinking counter-historically, backwards from Pärt to previous composers for the organ? Is it possible to look backwards and speculate for a moment about earlier, more uncertain, forms of the organ's breath and how they might relate to time? J. S. Bach was, it does not need saying, a richly theological thinker in music. The polymathic Albert Schweitzer (1875-1965), encouraged by the organist and composer Charles-Marie Widor (1844-1937), began the serious modern investigation of this with J. S. Bach: Le musicien-poète (1905), later developed in German as J. S. Bach (1908). Now no Bach scholar could ignore the role of Bach's faith in his music. Take, as a single example, the chorale prelude on Dies sind die heilgen zebn Gebot, BWV 678: 'These are the 
holy Ten Commandments'. This, in the Lutheran scheme, is the hymn on the descent of the Law to Moses, first described in Exodus 20. In Judeo-Christian history, that is to say, the hymn marks the beginning of the possibility of civilised life on earth under God, the beginning of the Law, and the possibilities of righteousness. It recalls the commencement of man's capacity to please the Lord both in worship and in deed. And to the gift of the Decalogue to humankind, Bach responds with a chorale prelude shaped as a remarkably expressive double canon, where both the right-hand accompaniment and the left-hand articulation of the cantus firmus are in canon-the musical form where one line is imitated at a fixed interval of both time and pitch. Here is the Law of the Hebrews and the working out of a particularly complex example of counterpoint, that practice of music that is exceptionally dependent on, and expressive of, laws.

The structure of Dies sind die heilgen zehn Gebot is interpretablea narration can be found that does not 'explain' the music but at least permits one to see one of the many meeting points between Bach's faith and the propositional architecture of his writing. But what about breath in his organ music? In the territory of the speculative, I wonder if, in other pieces, Bach had somewhere in his mind the notion of the organ's theoretical possibility to transcend human lungs' capacity-a possibility that would become even more real two centuries after his death-and thus to figure in sound a proximity to eternity. There could be many examples of this in Bach's work, supposing my point to have any merit. But one that strikes me in particular is the elongated, unbroken fugue subject of the Prelude and Fugue in $b$ minor, BWV 544, a cornerstone work in the organist's repertoire from Bach's Leipzig years. (There is, I should say, no certainty that the fugue subject should be played unbroken: it is, of course, possible to play it in groups of two notes, though the effect to my ear is laboured, or to introduce simply one or two articulation points. It is, in my experience, most often played without them.)

No ordinary singer could keep the long lines of this fugue, assuming they are unbroken, going without a breath; no ordinary string player could articulate this fugue subject all in one movement of the bow. Perhaps, as a listener attends to this long-breathed fugue subject and its counter-subject - the elongated lines of the counterpoint in general-he or she might be hearing Bach's intrigued meditation on the capacity of the organ, even one blown by hand or by foot, to offer us the beginnings of a glimpse of transcendence beyond our frail lungs, an airy hint 
of possibilities concerning life beyond the ordinary human capacity that later generations would know better. In the organ's extended breathing, Bach, even in the first half of the eighteenth century, might have speculated about what later artificially blown instruments would more pointedly suggest: that the organ can reach towards realms where breath does not run out. Stravinsky said, with a remark sometimes attributed to Berlioz, that the organ's steady wind - to return to my epigraph-was the reason he never wrote music for it: 'the monster never breathes', he said. ${ }^{37}$ Bach felt differently whether he was musing on eternities suggested by the organ's lungs or not. But those who played at St George's Hall, at Colston Hall, or at any of the newly powered organs of industrial modernity found, I think-so long as the wind supply worked-a more substantial confirmation of what Bach might just have been wondering. The act of switching on an artificially powered blowing system, strange though it is to say, could, perhaps, take one's poetically inclined listeners half-way to heaven.

Acknowledgments My gratitude for their comments on drafts of this essay or advice more generally to: Michael Brennan, John Butt OBE, David Fuller, Russell Goulbourne, Graham Huggan, David Pipe, and Iain Quinn. I am particularly grateful to Stephen Farr.

\section{Notes}

1. Brindley and Foster, Sheffield, was an influential provincial organ building company from 1854. They were eventually bought by Henry Willis and Co. in 1939. The view of the musicality of unstable wind for an organ-if that is what is being implied in this article-is hardly accurate (Bach, for one, complained about it). I turn at the end of the essay to the unmusical realities of poor wind supplies.

2. Frances Elizabeth Cox (1812-97); Christian Fürchtegott Gellert (171569). The text is the first verse of Hymn 117 in William Henry Monk, compiler and arranger, Hymns, Ancient and Modern, for Use in the Services of the Church (London: Novello, [1861]). The revised version, now widely used, removes the theological problem though not the need to breathe over the line end: 'Jesus lives! thy terrors now | Can, $\mathrm{O}$ death, no more appal us'. The original version proved particularly problematic in the index of first lines $(\mathrm{x})$.

3. The Cambridge Edition of the Poets: Wordsworth (New York: Houghton Mifflin, 1904), 541. 
4. Lawrence Ferlinghetti, These Are my Rivers: New and Selected Poems, 1955-1993 (New York: New Directions, 1993), 244.

5. Russell Goulbourne points me to William Cosmo Monkhouse (18401901)'s 'The Night Express', with its lines (as spoken by the locomotive):

'Now through the level plain,

While, like a mighty mane,

Stretches my endless breath in cloudy miles;'

Arthur Quiller-Couch, ed., The Oxford Book of Victorian Verse (Oxford: Clarendon, 1912), 654.

6. ' $[\ldots]$ And by ocean's margin this innocent virgin

Constructed an organ to enlarge her prayer,

And notes tremendous from her great engine

Thundered out on the Roman air [...]',

W. H. Auden, Collected Poems, ed. by Edward Mendelson (London: Faber, 1994), 280.

7. On the nature of the medieval organ, see, for instance, Peter Williams, The European Organ: 1450-1850 (London: Batsford, 1966); Kimberly Marshall, Iconographical Evidence for the Late-Medieval Organ in French, Flemish, and English Manuscripts, 2 vols (New York: Garland, 1989); and, on England specifically, Stephen Bicknell's The History of the English Organ (Cambridge: Cambridge: University Press, 1998).

8. For more details, see Andrew Parker, Winchester Cathedral Organs: One Thousand Years (Winchester: Culverlands Press, 2002).

9. John Milton, Paradise Lost: The Text Reproduced from the 1st Edition of 1667 (London: Basil Montagu Pickering, 1873), Bk 1, 1l. 705-15.

10. The British organ builders Martin Goetze \& Dominic Gwynn Ltd have constructed three Tudor instruments based on surviving evidence both written and physical: for more details, see https://www.goetze gwynn.co.uk/story-suffolk-fragments-making-tudor-organs-dominicgwynn/, last accessed 3 September 2018.

11. Henry Purcell (music), Nicholas Brady (words), Hail! Bright Cecilia: see vol. 8 of the Purcell Society series: http://www.henrypurcell.org.uk/ purcell-society-edition/.

12. Ibid.

13. Laurence Elvin observes that the organ-builders Wordsworth of Leeds asserted that the first organ in the UK to be blown by a device powered by electricity was that built by them for 'Rudstone' Church, Bridlington (actually All Saints', Rudston) in 1889, in Organ Blowing: Its History and Development (Lincoln: Elvin, 1971), 79. The National Pipe Organ Register nevertheless records this instrument as 1888 and makes no mention of its blowing system or alleged priority. That does not mean that Elvin is wrong. 
14. On the history of the nineteenth-century organ, see in particular Nicholas Thistlethwaite, The Making of the Victorian Organ (Cambridge: Cambridge University Press, 1990) and Stephen Bicknell's History of the English Organ. For other accounts of the relationship between the organ and literature, see Francis O'Gorman, "'Blush, Sad Soul, What Harmonies Are These!” The Organ in Nineteenth-Century English Literature', Yearbook of the Royal College of Organists (2003-2004), 66-73, and Iain Quinn, The Organist in Victorian Literature (New York: Palgrave Macmillan, 2017).

15. Its present form is as described in the National Pipe Organ Register http://www.npor.org.uk/NPORView.html? RI=N00289, last accessed 4 September 2018.

16. Elvin, 34.

17. E. H. Turpin, 'The Organ and Organ Music, II', The Musical Standard 21 (16 July 1881), 34-36 (34). Turpin (1835-1907) was an early Fellow of the (Royal) College of Organists and later Honorary Secretary. He was, as it happens, interested in poetry and, among other things, edited and introduced a volume of Tennyson, The Palace of Art, and Other Poems (New York: Maynard, Merrill [1898]). He is commemorated in the Turpin Prize, awarded to the candidate gaining the second highest marks in the Practical Examination for the Fellowship of the Royal College of Organists (FRCO).

18. Arthur Weir, The Romance of Sir Richard: Sonnets, and Other Poems (Montreal: Drysdale, 1890), 117.

19. Edmund Gosse, Father and Son: A Study of Two Temperaments (London: Heinemann, 1907), 256.

20. Edmund Gosse, On Viol and Flute (London: Henry S. King, 1873), 119.

21. The National Pipe Organ Register survey is dated from 1899 (and gives the date of the fire as that year): it can be found on http://www.npor. org.uk/NPORView.html? RI=N03895, last accessed 24 August 2018.

22. Hardwicke Drummond Rawnsley, A Book of Bristol Sonnets (London: Hamilton, Adams, 1877), 111. Cf., in the same collection, the rather mundanely titled 'On Hearing the Organ in the Cathedral, While the Work in the Nave was Suspended', 15.

23. The Collected Poems of T. E. Brown (London: Macmillan, 1900), 95-96.

24. The Poetical Works of Edmund J. Armstrong: A New Edition (London: Longmans, 1877), 81.

25. Michel de Montaigne, 'On the Cannibals', Les Essais, trans. as The Complete Essays by M. A. Screech (London: Penguin, 1991), 229.

26. The Complete Poetical Works of Oliver Wendell Holmes (New York: Houghton Mifflin [1895]), 188.

27. Elvin is an important source but documentation in his study of organ blowing is almost non-existent. 
28. Elvin, 72.

29. Ibid., 71. James Kendrick Pyne (1852-1938) was Organist of Manchester Cathedral, 1875-1908.

30. Ibid., 35 .

31. Thanks to Michael Brennan for this observation via his father, a chorister at Liverpool before the Second World War.

32. Elvin, 34.

33. Jonathan Bate, 'Words in a Quantum World: How Cambridge Physics Led William Empson to Refuse “either/or"', Times Literary Supplement (25 July 1997), 14-15.

34. See https://www.aslsp.org/de/, last accessed 13 September 2018.

35. Although often pronounced as if the last name is German (<Peart $>)$, Estonian pronunciation as I understand it means that the $<\ddot{a}>$ is like the $<$ a $>$ in $<$ cat $>$.

36. See https://www.allmusic.com/composition/volumina-for-organ-mc0 002406515 , last accessed 13 September 2018.

37. See Igor Stravinsky and Robert Craft, Dialogues and A Diary (London: Faber, 1982), 79.

\section{Selected Bibliography}

Bicknell, Stephen. 1998. The History of the English Organ. Cambridge: Cambridge University Press.

d'Anchald, Philippe. 2018. The First Applications of Electricity to the Organ. British Institute of Organ Studies Journal 42: 143-60.

Elvin, Laurence. Organ Blowing: Its History and Development. Lincoln: Elvin, 1971.

Marshall, Kimberly. 1989. Iconographical Evidence for the Late-Medieval Organ in French, Flemish, and English Manuscripts. New York: Garland.

O'Gorman, Francis. 2003-2004. 'Blush, Sad Soul, What Harmonies Are These!' The Organ in Nineteenth-Century English Literature. Yearbook of the Royal College of Organists: 66-73.

Quinn, Iain. 2017. The Organist in Victorian Literature. New York: Palgrave Macmillan.

Thistlethwaite, Nicholas. 1990. The Making of the Victorian Organ. Cambridge: Cambridge University Press.

Thistlethwaite, Nicholas, and Geoffrey Webber, eds 2011. The Cambridge Companion to the Victorian Organ. Cambridge: Cambridge University Press. Williams, Peter. 1966. The European Organ: 1450-1850. London: Batsford. 
Open Access This chapter is licensed under the terms of the Creative Commons Attribution 4.0 International License (http://creativecommons.org/licenses/ by $/ 4.0 /$ ), which permits use, sharing, adaptation, distribution and reproduction in any medium or format, as long as you give appropriate credit to the original author(s) and the source, provide a link to the Creative Commons license and indicate if changes were made.

The images or other third party material in this chapter are included in the chapter's Creative Commons license, unless indicated otherwise in a credit line to the material. If material is not included in the chapter's Creative Commons license and your intended use is not permitted by statutory regulation or exceeds the permitted use, you will need to obtain permission directly from the copyright holder.

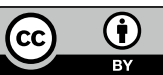

